\title{
Herännyt on hankala
}

\section{Anthony de Mello (1999). Havahtuminen.} LIKE: Helsinki

\section{Erno Paasilinnan kirjan}

Tähänastisen elämäni kirjaimet viimeinen luku alkaa arvoituksellisella lauseella: "Kirjoittaminen on pettymysten historiaa." Paasilinna tarkastelee kirjansa lopussa kirjailijoiden muistelmia ja tulee päätelmään, että kirjailijalla on surullinen loppu. Empiiristä katetta väitteelle löytyy niin Juhani Ahosta, joka loppuaikoina suostui puhumaan vain kalastamisesta kuin Pentti Haanpäästä, joka lopussa istui korpimökkinsä nurkassa puhumatta sanaakaan. Kuten tiedämme, vanhan Waltarin kohtalona oli kesästä kesään avuttomana tuskastella luomisvoimansa katoamista. Synkkiä kaikuja löytyy myös
Veijo Mereltä ja Paavo Haavikolta, jolta Paasilinna siteeraa: "Ihminen joka kirjoittaa on sen hetken maailmansa hallitsija, aivan avuton myös. Ei se ole ihmiselle luotu tila eikä asema." Itselleenkin Paasilinna luonnostelee samantapaista uraa: "Kun kirjoitan näitä viimeisiä rivejä, on toukokuun 26. päivä kello 14 iltapäivällä. Katson ulos: perhoset lentävät, ampiaiset hyörivät kukis- 
sa, ruoho on vihreää ja väkevää. Vihdoinkin kesä! Vielä on ainakin yksi kesä edessä, työ on tehty ja pääsen tästä vaivasta. Viimeinkin. Aika lopettaa."

\section{Paasilinna viittaa vielä}

Samuli Paroseen, kenties tärkeinpään esikuvaansa, jonka elämä ei ulkoisilta mitoiltaan ollut suuri ja jossa mikään hyvä ei kestänyt kauan. Paronen päättää kirjansa Maailma on sana seuraavaan aforismiin: "Katselen maisemaa, se tulee minuun, eikä mitään ole pois tulevilta, kun lähden."

\section{Kun lueskelen Anthony} de Mellon Havahtumista, eletään heinäkuuta, assosioituu Parosesta vielä yksi merkittävistä, Lauri Viita, jonka päivät päättyivät tapaturmaisesti auto-onnettomuudessa. Viimeiseksi jääneen Onni-sikermän loppuun, sikermän, joka ilmestyi kuolinpäivänä Parnassossa - mahtoiko olla sattumaa -, Viita kirjoittaa: "Kaita polku kaivolta ovelle/ nurmettuu./ Ikkunan edessä/ pystyyn kuivunut omenapuu./ Reppu naulassa ovenpielessä,/ siinä linnunpesä./ Kun olen kuollut, kun olen kuollut./ Kesä jatkuu. Kesä.”

\section{Ratkeaako riita maailman} kanssa vasta fyysisen tai psyykkisen lopun lähestyessä, onko pohdiskeltava vanhuuteen vai voiko sovituksen saada aikaisemmin? Kirjailijakohtaloissa on epäilemättä kysymys jonkinlaisesta havahtumisesta ja toisen asteen heräämisestä. Ensimmäisen heräämisen jälkeen on tehty töitä paljonkin, sanoja soviteltu ja käytelty, luotu lauseita, mutta lopulta jouduttu tunnelmaan, että sittenkin vähän on kai- kesta jäänyt käteen. Maailma on se, mikä se on ilman minuakin, ponnistelujani, taistelujani. Ehkä en varsin pahaa ole kirjoituksellani tehnyt, mutta en juuri niin hyvääkään. Kirjoittaminen on pettymysten historiaa, mutta jälkipuoleltaan myös todellisuuden tajua, todellisuudelle myöntymistä, todellisuuden tulemista minuun. Jotain kenties sittenkin jatkuu myös minusta.

\section{Millaiseen kulttuuriseen} koodiin näin lohduton tilinpäätös perustuu? Mikä on se, mistä havahdutaan? Mistä sovitus saadaan, jos saadaan? Mikä panee toistamaan näinkin voimallisesti samaa tarinaa (mies)kirjailijan lopusta? Ehkä ei ole liian uskaliasta ajatella, että taustamyyttinä vaikuttaa länsimaisen maailmankuvan patriarkaalis-individualistisen voittamisen, valloittamisen ja pärjäämisen ideaali, jonka toinen potenssi näkyy talouskoneiston vastaansanomattomana voittokulkuna.

\section{Vaikka kirjailijan työ ja} vaiva onkin pörssipeluriin verrattuna hyttysen ininää, piiskaa ideaali myös kirjailijaa eteenpäin "taistelussa" sanansäilällä maailmaa vastaan. Siinä missä sijoittajan unelma on kurssiheilahduksen ennustaminen, unelmoi kirjoittaja kauniista tai kumouksellisesta, ehkä käyttämättömästäkin, lauseesta. Vaikka länsimainen ihminen ei ehkä voikaan lakata toimimasta, on toiminnan päämäärillä ja vaikutuksilla eroja.

\section{Tästä ajatuksesta voi} aukaista myös sielunhoidon opettajan, jesuiittaveljeskunnan jäsenen, Anthony de
Mellon kirjan Havahtuminen, joka esittää hybriselle länsimaisuudella kokolailla vastaisen tavan ajatella elämästä, elämän päämääristä, ja lopulta, onnellisen elämän tarkoituksesta. Kirja antaa mahdollisuuden monenlaisiin lukutapoihin, kuten painotuotteet yleensä. Lukemista nopeuttavat tarinointi, vertaukset ja runsaat toistavat ja pääasioihin palaavat ydinideat. Toisto ja paluu ovat de Mellon metodeita. Niillä lukija yritetään saada havahtumaan, kuten huomataan, ilman pakottavaa tarvetta alleviivauksiin. Kirjan voi monien mahdollisten luentojen lisäksi asettaa erilaisiin keskusteluyhteyksiin. Yhden antaa populaari terapiakirjallisuus, toisen sarasvuomaiset psyykkausoppaat, joista Heikki Mäki-Kulmala tietää kertoa yhden jos toisenkin seikan. Kolmas nousee perinteestä, jota meillä tunnetaan vähän: oman ajattelujuuristomme kadotetusta viisaudesta, joka palautuu arabialaisen kulttuurin mystiikkaan ja mytologiaan, ja niistä johtuviin idänfilosofioihin. Kulttuurimme juuristoa meillä alkaa onneksi olla saatavilla korkealuokkaisina käännöksinä kiitos professori Jaakko HämeenAnttilan Koraanin ja Gilgameshin uusien käännösten. Neljäs keskustelukonteksti, jossa kirjaa voi lukea, löytyy erilaisista terapiakäytännöistä, joiden edustajilla varmasti on paljon sanottavaa de Mellon prinsiipeistä omissa legitimaatiokamppailuissaan ihmisparkojen sieluista. de Mello korostaa, että onni ja autuus eivät löydy jatkuvasta eteenpäin pyrkimisestä, uuden tavoittelemisesta, sanalla sanoen halusta, tahtomisesta ja yrittämisestä. Tahto- 
minen (valtaan, tietoon) on nostettu filosofisissa ja ajattelun historiallisissa esityksissä (jatkumolla Nietzsche-Foucault) länsimaisen ihmisen olemassaolon perusolettamuksiksi. de Mellon mukaan on lakattava tahtomasta. Tahtomasta lakkaamisen on tapahduttava pakottomasti ja juuri tässä on kirjan sisällön vaikeus länsimaiselle lukijalle, jonka tapa on etsiä itseään paloittaisesti milloin tästä riemudieetistä, milloin tuosta hiljaisuuden retriitistä.

\section{Ensimmäisenä havahtu-} miseen johtavana kirjana Havahtuminen voi olla pettymys. Se on liian vaikea, se ei tarjoa selkeitä ohjeita elämän autuuteen, mutta juuri tässä on sen metodi: kirjan lukijakuntaa ovat tavalla tai toisella nykyaikaiset kiirastulensa läpikäyneet ihmiset, jotka ovat jo miettineet näitä asioita. Heille kirja voi olla iso elämys, sillä se alkaa viattomalla kysymyksellä minästä, kysymyksellä, josta isolla osalla meistä ei ole harmainta aavistusta arkipäivän hälinässä ja touhottamisessa: "Tarkoitatteko, että ymmärrätte astronomiaa, mustia aukkoja ja kvasaareita ja olette oppineet automaattisen tietojenkäsittelyn, mutta ette tiedä, kuka olette? Olette yhä unessa. Olette nukkuva tiedemies."

Kiinnostavaa on, että de Mello päättää kirjansa A. S. Neillin Summerhill-kirjan referointiin. Sieltä hän löytää tärkeitä esimerkkejä päättelemään omia teesejään. Meillähän Summerhillistä puhuttiin aikanaan paljonkin, mutta tavoitettiinko sittenkään kirjan ydintä? Uskoakseni ei. Ikävä sanoa, mutta useimmat tekstit jäivät moralistisessa korskeudessaan valovuoden päähän Neillin perusteeseistä. Eräs osuva luonnehdinta sentään suomalaisestakin aikalaiskeskustelusta löytyy. Pentti Holappa on oivaltanut Neillin pedagogisen ytimen pienessä kirjoituksessaan "Onnellista kasvatusta": "Neill ei pidäkään tavoitteenaan niinkään opettamista kuin onnellisten ihmisten kasvattamista, mutta nämä onnelliset ihmiset ovat myös sopeutumiskykyisiä. He selviytyvät kieroutuneessakin yhteiskunnassa ja pystyvät halutessaan myös hyviin oppisuorituksiin." Oivallus ja viisaus sisältyy sanoihin 'pystyä' ja 'halutessaan', jotka kertovat nykyisin unohdetuista inhimillisten mahdollisuuksien kirjosta.

\section{Ajatuskokeena voi}

kuvitella, millainen olisi de Mellon havahtunut, herännyt, itsestään ja toimistaan tietoinen kanssaihminen. Millainen olisi ihminen, josta näkisi onnen, joka valitsisi seuransa tahtonsa eikä vähimmän mielipahan periaatteen mukaan, kirjoittaisi ja puhuisi, kuten asiat näkee, kiertelemättä, kaartelematta, ketään kumartamatta, hyväksyisi luuseriuden yhtä hyvin kuin lamborghinit panematta näille asioille paljon painoa, antaisi masennuksen tulla ja mennä, päästäisi ilon ja surun vaeltamaan itsensä läpi, ei tulisi mistään hinnasta imarrelluksi, ei liioin pahoittaisi mieltään tyhmyyden edessä? Ehkä jokin sellainen, jonka löydän Kalle Holmbergin äskettäin lukemistani sanoista: "Eräänä päivänä ymmärsin, että en pitänyt ihmisistä. Sinä päivänä tulin vapaaksi ja palasin heidän luokseen."

\section{Luultavasti de Mellon}

hahmottelema onnellinen ihminen, ja edustamansa onnellinen elämäntapa, olisikin sosiaalisesti kestämätön. Holmbergin vapautuneella ihmiselläkään ei ole muuta mahdollisuutta kuin tulla väärinymmärretyksi, mutta kuten de Mello opastaa, tämä ei järkyttäisi vapautunutta ihmistä. Emme kestäisi peiliä, joka osoittaa teeskennellyn sosiaalisen toimeliaisuuden määrän, johon hukuttaudumme sillä aikaa kun elämä tapahtuu meille. Hän olisi niin kestämätön, että meidän olisi tavalla tai toisella päästävä hänestä eroon, kenties hänet olisi tapettava, kuten tapetaan Platonin luolaan palaava, peitteettömän todellisuuden nähnyt. Silti de Mellon opas havahtumiseen on lukemisen arvoinen, kumouksellinenkin kirja, joka laittaa kysymään, mihin aikansa on tuhlannut. Onko aikaa ollut istua yksin hiljaa ja miettiä tärkeimpiä asioita, onko ollut aikaa tärkeimmille ihmisille? Onko ollut aikaa herätä pärjäämisen mauttomasta eetoksesta, pois ohjelmoidusta arjesta ja löytää sisältään arvostelukykyinen luuseri, ajatus, joka pitää sisällään vallankumouksen? de Mello osoittaa, miten vähän siedämme onnellisuutta, menestystä, kritiikkiä ja niistä kasvavaa arvostelukykyä. Sen sanoi aikuiskasvattaja ja -kasvanut Samuli Paronen: "Toivealamaisella ei ole omaa arvostelukykyä. Hänen tilanteensa ovat ohjelmoituja. Kun hän herää ja vertailee, hänestä tulee hankala."

Juha Suoranta 